\title{
TECHNOLOGY'S ROLE IN COMMODIFICATION OF NOT-FOR-PROFIT MEDIA
}

\section{G. SREEKALA}

Department of Communication, University of Hyderabad, India

\begin{abstract}
This study explores the role of technology in providing an extended public sphere of participatory democratic discourse. By examining the case of 'the wire.in,' an Internet-based journalism, the study analyses how technology shapes up and impacts the startup's practices and structures that eschew the advertiser-subsidised, corporate-owned business model of the mainstream media. Empirical data for the study is derived by integrating qualitative analysis of the in-depth interviews conducted by the founders, staff, and contributors of the wire. in and mainstream journalists and a wide assortment of texts related to the startup. The findings show that while technology makes it easier and cost-effective to set up an Internet-based journalism site and distribute content, it does not work as insulation against corporate influence. The wire.in depends on social networking sites, owned by multinational corporations to advertise and distribute content, thereby making itself and its content become a commoditized product on social media. This undermines the startup's democratic potential to provide an extended public sphere.
\end{abstract}

KEYWORDS: Technology, Public Sphere, Commoditisation, Media Startup, Business Model \& Corporate Influence

Received: Jul 28, 2017; Accepted: Aug 16, 2017; Published: Oct 13, 2017; Paper Id.: IJCMSOCT20177

\section{INTRODUCTION}

With corporate controlled mainstream media in India increasingly coming under criticism due to its profit maximisation strategies, it is time to look at the possibility of an alternative media and a non-profit business model that can help redefine the production and distribution of news. Along with the rising adoption of Internet in the country, a number of online news media organizations have come up claiming to offer an independent, alternative space for journalism. These organizations believe new media technologies, especially the Internet; hold the potential to bring about a change in the way media function in the country (Sen\& Nielsen, 2016, Robinson, Grennan and Schiffrin, 2015, Bearak 2014, Kohli-Khandekar, 2013).

There should not be any doubt that economically backward, diverse and pluralistic Indian society needs an alternative media, free from the powers of private and political forces to inform people and act like a watchdog over the government and other social institutions. India has over 135 news channels, of which a third are owned by politicians and real estate barons and in its effort to expand its economic interest media often indulge in promoting political propaganda. "After the 2009 general elections, it was discovered that some of the largest newspapers took cash to print or not print news about a candidate" (Kohli-Khandekar, 2014). While circulation revenues constitute just 5-15 per cent revenues of English newspapers, TV news in India is almost completely dependent on advertising. Unlike broadcast companies internationally that make 55 per cent of their revenues from subscription or pay, in India advertising contribute 80 per cent of a news channel's revenues (Kohli-Khandekar, 2010, p. 90).

In this context, it is pertinent to look at technology's potential, in facilitating the adoption of a new media 
business model that does not involve corporate funding. The importance and sustainability of traditional media, profitability of online business models and crowd funding, state funding and non-profit media has long been a subject of study for scholars (Hustad, 2013; Madrigal, 2011; Bollinger, 2010 et al.) in the west. However, in India, there hardly exist any studies that look at the business model of online media. This paper, therefore, analysed the practices and structures of an Internet-based news media startup in India--The Wire (www.thewire.in)to understand the role played by technology to offer an extended public sphere for participatory and democratic discourse, free from commoditization and corporate influence.

\section{Commercialization of Audience Commodity}

Smythe (1981, p. 1-51) suggested that, what goes on in mass communication is not primarily audience consumption of media content - produced by media corporations - but, in fact, the selling of audience attention to advertisers. This formulation rendered the audience as an active participant in the political economy of mass communication. Smythe's notion of the work of the audience revolves particularly on cognitive and emotional work: learning to desire and buy particular brands and commodities. Analysing social media using Smythe's theory, Fuchs (2011) said Facebook and the capitalist parts of web 2.0 engage in Internet prosumer commodification. He argued that, using the same accumulation strategies employed by traditional capitalist media, social media sell user data to advertiser for profit. Corporate advertisers shell out money to access personal data of social media users as this economic surveillance helps target advertising. Using Fuchs' theory, this paper analysed how commoditization and commercialization of audience happen in the case of the Wire through the use of social media.

\section{METHODOLOGY}

This paper is part of a larger exploratory study of the political economy of digital news media entrepreneurship in India. Hollifield and Coffey (2008, p 574) say qualitative methods are valuable for "exploratory research, where the researcher is seeking to identify variables and issues. Creswell (2009) also favors a qualitative approach to exploratory research, where the aim is to understand a little researched or completely new phenomenon or topic. The paper employs a case study method to gain insight into the technological practices of the online media startup -- The Wire. In this study, the startup's use of technology is the primary focus of the research. The Wire was selected for the study due to its non-profit ownership structure and lack of advertisements on its site to understand the firm's business model.

The empirical evidence in this paper is collected by integrating qualitative analyses of three types: 1) Six semistructured interviews with the founders, editorial staff, contributors, and funding partners of The Wire; 2) a wide assortment of texts related to The Wire, including news reports, trade material, research reports and published interviews of the founders and the funding partners of the startups under study; and 3) 15 informal interviews with mainstream journalists. Of the total 21 interviews, 17 were done face-to-face while three were done by phone and one on Skype. The interviews done during October 2014 - May 2015, were recorded and were transcribed manually. The transcriptions were later sent to interviewees for their approval. The data gathered through interviews were analyzed using thematic coding (Flick, 2009, pp 318-323).

\section{FINDINGS AND DISCUSSION}

Founded by veteran journalists Siddharth Varadarajan, Sidharth Bhatia and MK Venu, The Wire started its operations in May 2015. The Wire aims to be a media driven by editors and not advertisers. Blaming the mainstream media 
advertising-subsidized business model for the eroding professional standards of journalism, the founding editors wanted The Wire to be a not-for-profit organization supported by grants and contributions from individuals. In May 2016, The Wire had 10 employees apart from the three founding editors and after a year later in April 2017, its staff strength went up to 20 .

\section{Commoditization and Advertising on Social Media}

When looked through the lens of audience commodity, it seems The Wire differs from the mainstream media by not hosting ads and thereby do not produce readers and audience as a commodity and sell it to advertisers in return for revenues. This, however, does not imply a complete absence of commoditization and commercialization. No media can exist without an audience and The Wire is no different. The Wire uses social media -- Facebook and Twitter -- to market its content and reach out to the audience. Social media, the interview participants say are 'critical' for them. They considered Facebook and Twitter, as their main sources of distribution, as P1 ${ }^{1}$ said, "Without social media people will not come to the site."

The participants admitted that their dependence on social media is in stark contrast to their declared stand against corporate funded and controlled media as both Facebook and Twitter are large profit-oriented multinational corporations. But they thought they did not have any other option but to depend on these MNCs for reaching out to the audience as The Wire was not "very well-known." They hoped that their dependence on social media would reduce once The Wire grew into a known entity. They noted that "the importance of social media will still be there, but it will be relatively less than what it is today."

Fuchs (2011) said Facebook presumes "are first commodified by corporate platform operators, who sell them to advertising clients and, secondly, this results in their intensified exposure to commodity logic." This led them to being the 'double objects of commodification.'

As ad-free online media organizations, The Wire does not produce audience/reader as a commodity directly. But the reliance of The Wire on social media -- Facebook and Twitter -- for reaching out to audience and distributing/marketing content point towards the existence of commoditization and commercialization, albeit indirectly. Its presence on corporate owned and controlled social media means that The Wire is exposed to the capitalistic logic of commoditization. This capitalist logic of commoditization is on full display, when the Wire tries to attract an audience on social media, by putting its content on social media sites to attract audience. In this process, The Wire becomes an advertiser in itself and its content on social media becomes the advertisement. Its content can no longer be distinguished as either news or advertisement. In this process, The Wire, its content along with The Wire becomes commoditized products of the social media. In other words, there is a dialectical tension between the existence of The Wire as an ad-free, nonprofit media that is different from the corporate owned and controlled traditional media and its presence on social media as an advertiser and commodity.

Despite its dependence on Facebook and Twitter makes The Wire vulnerable to online censorship, the interview participants felt there was much democracy in social media. Narrating an incident, where Facebook blocked an article written by a former diplomat for The Wire, criticizing the present government, and subsequently reinstating it due to online protest, P3 said, "for their own survival, these social media MNCs may not control the content. They could not afford to

\footnotetext{
${ }^{1}$ Interview participants are not identified by names to protect confidentiality 
dilute their brand by censoring or cozying up to any governments."

However, the economic and political interest of the private corporations and the state is a powerful force that can undermine the perceived democratic nature of the social media. Advocating for a public service social media "that transcends particularistic control and represents the public interest,' Fuchs (2014) says state institutions use the Internet and social media for surveillance. Citing Edward Snowden's revelations about the existence of the Prism system, Fuchs argues that the 'military-industrial complex works to serve the state's political interest by collecting users' personal data.

But the surveillance is not limited to monitoring terrorists' activities alone. As Hodai's (2013) report on Occupy WallStreet shows state institutions use social media to surveil upon civil society activists and others protestors, as well. Private corporations are willing partners in this surveillance game. On the one hand, social media offers a platform for contemporary activists to voice their protest and political demands. On the other, the same social media along with state institutions wields 'the power to directly or algorithmically control political movements' internal and public communication capabilities' (Fuchs 2014). This power to control dissent on social media indicates that if the economic and political interest of the private corporations or the government comes under threat, they will not hesitate resorting to censorship. At McChesney (2010, p. 142) writes, the elimination of privacy means 'the threat of state harassment is greater today than ever before.'

\section{Non-Profit Media and For-Profit Technology}

The interview participants unequivocally said technology helped The Wire to keep the operating cost at a minimum. According to them, the cost of setting up an online media organization is very low compared to traditional media like print or TV. At the time of the interviews The Wire had only one formal office in Delhi. As a result, it incurs almost no infrastructure related expenses. Despite a decentralized set up where each member is located in different cities -Mumbai or Bangalore -- coordination and connectivity never pose a problem in the functioning of The Wire, due to technology. As P3 explained, The big advantage of the web is that unlike mainstream media you do not have to spend anything on distribution. The web media immediately by its very nature opens distribution to anybody. Internet media have a great advantage as entry barriers are low. We launched the entire site with a capital base of about Rs 10 lakh. It shows that, such a small capital investment can create such a disproportionate influence on the web, in terms of competing with other media organizations.

Although the participants are optimistic about the potential of the technology, they admitted that the news gathering (reporting) cost is the same as that of mainstream media. While The Wire depended on technology for production and distribution of content, P1 said "we should not make grand judgments on technology like net is the answer to all our problems." He pointed out that at the moment everyone is rushing into online media. "The big groups are finding technology very sexy." He believed that it was difficult to predict how it was going to be after five years. "There will be people making silent compromises and nobody will come to know about it."

His fears stem from the fact that it is easy to control the technology as much of the potential of technology in providing democratic online space depends on government policies. As P1 says, "So far everything is open. How do you know what kind of rules the government is planning?"

These fears are in line with McChesney's stand on technology. As Mc Chesney (2010, pp. 142-143) argues, "The openness of the Internet is due to the policy as well as technology. Telecommunication companies and cable companies 
have the power to censor the Internet and work hand-in-hand with the governments that grant them monopoly licenses."

In this context, it can be inferred that The Wire is just a user of the Internet technology. It does not own or control the technology and the Internet is dominated by capitalist structure. As a result, The Wire cannot dictate the conditions of production. Besides, being a media organization, distribution of content is extremely important for The Wire. As discussed earlier, The Wire depends on social media, owned by private corporations to distribute its content. Although social media act as free channels of distribution, it is completely controlled by for-profit corporations. They control The Wire's access to its audience. As Fuchs (2011) says, on social media prosumers become unpaid workers, generating content for the corporations. By putting out its content on social media The Wire generates content for the private corporations and in return gain access to distribution channels and audience. While the content produced by The Wire becomes a revenue generating product for the social media, the creator of the content -- in this case-The Wire -- does not get paid for its labour. This exploitation is the fee The Wire that has to pay to gain access to social media, to gain access to an audience.

Technology helps The Wire to produce content at relatively low cost in a decentralized manner. Here again, if The Wire were to employ more paid professionals to produce content, its cost will be on par with other traditional media. Currently, the site depends heavily on voluntary contributions for the majority of its content needs. Therefore, the only cost the firm saves with the use of technology is that of a formal office and related physical infrastructure. As noted earlier, the distribution of the content produced involves exploitation and compromise on independence. And, for any media it is the distribution of content that is vital to its success. Therefore, the entire existence and survival of The Wire currently depends on corporate controlled technology.

Besides, The Wire uses the services of US-based Disqus, a comment management platform. In this process, The Wire becomes its partner, providing a large number of users to Disqus, leading to the commoditization of readers. Disqus in turn track these readers and sell their personal information to third party advertisers, thereby commercializing the user data. On the Disqus site (www.disqus.com) under terms and policies, the company has given a detailed description of its policies on collecting user data and sharing it with third parties for advertising and marketing purposes. Dusqus shares this browser history, and other personally identifiable information will be used for promotional and marketing purposes. Disqus tracks users and sell their personal data to third party companies, who want to target the users for advertisement.

Habermas considered the public sphere to be independent of economic and political power (Habermas 1991, 36). However, The Wire cannot be considered as an extended public sphere due to its dependence on social media and other for-profit technological applications. Although The Wire does not chase profits, it indirectly becomes an active agent that contributes to the profit of social media.

\section{CONCLUSIONS}

This case study of The Wire shows the complex and challenging problems faced by an online media startup in its effort to provide an alternative space for journalism. Analysis of the functions and structures of The Wire points towards a media that is trying to move away from the business model, adopted by the mainstream media in India. It is with this objective that The Wire is registered as a not-for-profit company. However, in a capitalist society, it is not easy to be completely independent of the market system. As the findings show The Wire is trying to create an alternative space, but it is getting subsumed by the existing system. Notwithstanding its belief in the Internet, it is the technology that works as a catalyst and produces audience commodity. The technology controlled by social media MNCs makes use of The Wire and 
its contents for profit. In this process, The Wire becomes the advertiser of its own content. Technology's potential to bring about an extended public sphere not controlled by the state or capital, becomes questionable when the technology itself is a product of the capitalist system controlled by corporate.

\section{REFERENCES}

1. Bearak, M. (2014, May 25). Global Digital News Brands See Growth Opportunity in India. The New York Times [New York]. Retrieved from https://india.blogs.nytimes.com/2014/05/25/global-digital-news-brands-see-growth-opportunity-in-india/?_r=0

2. Bollinger, L. (2010, July 15) Why we should dare to consider state funding to preserve journalism. The Guardian. Retrieved from http://www.theguardian.com/media/greenslade/2010/jul/15/downturn-pressandpublishing

3. Creswell, J.W. (2009). Research Design: Qualitative, Quantitative and Mixed Methods Approaches. Thousand Oaks, CA: Sage Publications.

4. Flick, U. (2009). An Introduction to Qualitative Research, (3rd ed). London, UK: Sage Publications.

5. Fuchs, C. (2011). Web 2.0, Prosumption, and Surveillance. Surveillance \& Society 8 (3): 288-309. Retrieved from file:///C:/Users/Acer1/Downloads/4165-7261-1-PB\%20(1).pdf

6. Fuchs, C. (2014). Social Media and the Public Sphere, triple, 12(1): 57-101. Retrieved from file:///C:/Users/Acer1/Downloads/552-2008-1-PB.pdf

7. Habermas, J (1991). The Structural Transformation of the Public Sphere. An Inquiry into a Category of Bourgeois Society (pp.1-52). Cambridge, MA: MIT Press.

8. Hodai, B. (2013). Dissent or Terror: How the Nation's Counter Terrorism Apparatus, in Partnership with Corporate America, Turned on Occupy Wall Street. Center for Media and Democracy, DBA Press. Retrieved from http://www.prwatch.org/files/Dissent\%20or\%20Terror\%20FINAL_0.pdf

9. Hollifield, C.A. and Coffey, A.J. (2008). Qualitative Research in Media Management and Economic. In Albarran, A.B. (Ed.), Handbook of Media Management and Economics (p.574- 587). Mahwah: NJ: Lawrence Erlbaum Associates, Publishers.

10. Hustad, K. (2013, October 24) Kickstarting journalism: Is crowdfunding the answer? The Christian Science Monitor. Retrieved from http://www.csmonitor.com/Technology/2013/1024/Kickstarting-journalism-Is-crowdfunding-the-answer

11. Kohli-Khandekar, V. (2010). The Indian Media Business (p.90). New Delhi: Sage Publications.

12. Kohli-Khandekar, V. (2013, November 18). India online, on the go. Business Standard. Retrieved from http://www.businessstandard.com/articlelopinion/vanita-kohli-khandekar-india-online-on-the-go-113111801029_1.html

13. Kohli-Khandekar, V. (2014, August 19). Trai's take on media ownership. Business Standard. Retrieved from http://www.business-standard.com/article/opinion/vanita-kohli-khandekar-trai-s-take-on-media-ownership114081901350_1.html

14. Madrigal, A.C. (2011) What Big Media Can Learn From the New York Public Library. The Atlantic. URL: http://www.theatlantic.com/technology/archive/2011/06/what-big-media-can-learn-from-the-new-york-public-library/240565/

15. McChesney, R.W. (2010). The Political Economy of Media: Enduring Issues, Emerging Dilemmas. New Delhi:Aakar Books.

16. Robinson, J. J., Grennan, K., \& Schiffrin, A. (2015). Publishing for peanuts Innovation and the Journalism Start-up. Retrieved from http://www.cima.ned.org/wp-content/uploads/2015/11/PublishingforPeanuts.pdf

17. Sen, A., \& Nielsen, R. K. (2016). Digital Journalism Start-Ups in India. Retrieved from Reuters Institute for the Study of Journalism website: $\quad$ https://reutersinstitute.politics.ox.ac.uk/sites/default/files/Digital\%20Journalism\%20Start- 
ups\%20in\%20India_0.pdf

18. Smythe, D.W. (1981). Dependency Road: Communication, Capitalism, Consciousness, and Canada (1-223). Norwood, NJ: Ablex Publishing 
